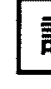 \\ 低圧水銀一アルゴン・アフタグローに扔ける プローブ特性と両極性拡散係数の測定
}

\author{
正 員 山 根 幹 也 (電通大) \\ 非会員 名 取 乾 治 (電通大) \\ 非会員 石 田 信 之 (電通大)
}

\section{Measurements of Probe Characteristics and Ambipolar Diffusion Coefficient in Low Pressure $\mathrm{Hg}$-Ar Afterglows \\ Mikiya Yamane, Member, Kenji Natori, Non-member, Nobuyuki Ishida, Non-member (Univer- sity of Electro-Communications)}

Time-resolved Langmuir probe technique has been applied to the afterglow of pulsed discharge in low pressure $\mathrm{Hg}-\mathrm{Ar}$ mixtures. The basic procedure consists in applying a ramp voltage, with a rise time of the order of a few minutes, to the probe and sampling with a 2-channel boxcar integrator the probe current and the probe voltage at specified times during the afterglow. The probe current $\triangleright$ voltage characteristics during the most portion of time of the afterglow exhibit normal curves for the positive ion saturation region, transition region and the electron saturation region, giving quite reasonable results of electron temperatures, plasma densities and space potentials respectively. From the logarithmic plotting of the plasma density against time we have obtained the ambipolar diffusion coefficient $D a p=350 \mathrm{~cm}^{2} \cdot \mathrm{s}^{-1} \cdot$ Torr, in good agreement with calculated value $D a p=360 \mathrm{~cm}^{2} \cdot \mathrm{s}^{-1} \cdot$ Torr, which is derived using Chanin's atomic mercury ion mobility in argon.

An unexpected result is that the probe characteristics just after the cut-off of the pulsed discharge (within $100 \mu \mathrm{s}$ after the ionizing field is removed) demonstrate the presence of high energy electrons. These are assigned to the acceleration by the field that possibly occurs between the plasma and the wall of the discharge tube.

キーワード : 水銀-アルゴン混合気体, アフタグロー, 時間分解プローブ測定, 両極性拡散係数

\section{1.まえがき}

パルス放電アフタグローから放出される放射を時間 分解分光し，記録したスペクトル線の隇衰曲線からイ オンー分子反応の速度係数, 両極性拡散係数などを求 めてきたが(1)(2)，この時間分解測定の手法をプローブ 測定に適用してプラズマの密度, 電子温度, プラズマ 電位の時間的変化の測定を試みた。

変動するプラズマの電子密度, 電子温度などのプラ ズマ物理量の測定にしばしばダブルプローブが用いら
れている。しかしシングルプローブを用いると,プラ ズマ電位，電子のエネルギー分布などを含むより多く の情報が得られる利点がある。この変動プラズマに対 するシングルプローブ測定法を下記のように分類する ことができる。

（1） point by point 法 変動プラズマの特定位 相（時刻）においてパルス電圧をプローブに加え，プ ローブ電圧, プロープ電流を読取る。逐次このパルス 電圧を変えてその位相におけるプローブ特性曲線を得 る測定法(3)(4)，またはプローブに一定の直流電圧を加 
えて周期的に変動するプラズマの1 周期の電流波形, 電圧波形を記録し，逐次直流電圧を变えて測定を反復 する方法もある(5)。

（2）電圧掃引法（sweep 法）高速の鋸米状波 のパルス電圧をプローブに加えて電流一電圧特性を記 録する方法(6)(7)，あるいは低速の ramp(傾斜) 電压を 印加する方法，すなわちプラズマの変動速度に比へて はるかにゆっくり上昇（低下）する電圧を印加し，こ の電圧の各点でプローブ電圧, プローブ電流を繰返し サンプリングすることによりプローブ特性を記録する 方法がある(日)。

本論文は,この最後に述べた低速 ramp 電圧揥引法 を $\mathrm{Hg}-\mathrm{Ar}$ ランプのパルス放電に適用し，アフタグロ 一の各時刻におけるプローブ特性の測定結果について 報告する。主として意図するところはプラズマ密度, 電子温度の測定, 両極性拡散係数の決定であって, こ のため電流を微分して電子エネルギー分布を決定する ようなところまでは立ち入っていない。

\section{2. 時間分解プローブ測定装置と測定方法}

図 1 は時間分解プローブ特性を測定する実験装置の 構成図である。パルス放電プラズマを発生させるパル ス電源, 熱陰極アルゴン-水銀放電管, 放電管のプロ

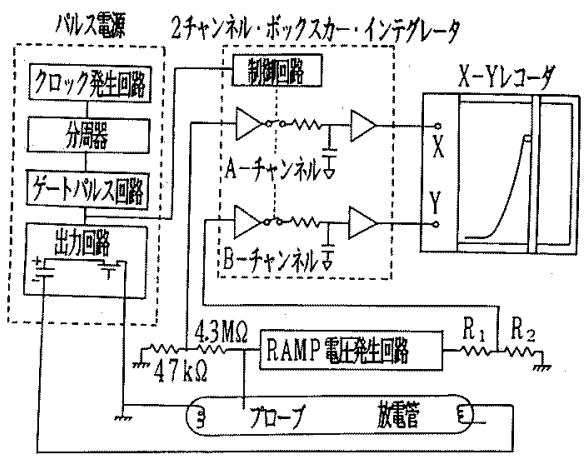

図 1 実験装置の構成図

Fig. 1. Block diagram of apparatus.
ーブ電圧回路としての ramp(傾斜) 電圧発生回路, およびプローブ電圧, プローブ電流を時間分解して測 定するボックスカーインテグレータ， $X-Y$ 記録計か ら粠成されている。放電管は殺菌ランプ GL-6(石英 管外径 $15 \mathrm{~mm}$, 内径 $13 \mathrm{~mm}$, 電極間距離 $150 \mathrm{~mm}$ ) と同じ大きさの軟質ガラス放電管で, $1 \mathrm{~mm} \times 0.4 \mathrm{~mm} \phi$ のプローブが設置されている。水銀-3 Torr アルゴ ン，水銀-6 Torr アルゴンの 2 種類の放電管を用いて いる。封入圧がやや高いのは再結合放射の実験(1)(2)k 対比できる相補的データの取得を意図しているからで ある。このためシース内におけるプローブ流入電子 (イオン) の衝突は無視できないが，〈3・3〉，〈3・4〉節 でその影響について言及する。

放電管にパルス電圧が印加されているときの陽極は

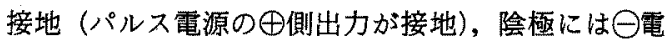
圧が加かるので点灯中のプラズマ電位はきの状態にあ る。アフタグローの期間では陰極は陽極と同電位にあ りまたプラズマ電位もほほ接地電位にある。プロー ブ電圧回路としての ramp 電圧発生回路はこのプラズ マ電位近傍の電圧範囲を掃引しなければならないが， 図 2 の積分回路がこの要求を満たす。この回路注電力 用 OP アンプ PA $12 \mathrm{~A}$ (Apex 社製品) を用い，ツェ ナーダイオード HZ-4(ツェナー電圧 $\left.V_{Z}=4 \mathrm{~V}\right), \mathrm{HZ}-$ $5\left(V_{z}=5 \mathrm{~V}\right), \mathrm{HZ}-6\left(V_{z}=6 \mathrm{~V}\right)$ に上る差動入力電圧 を積分して出力するもうとも一般的な積分回路であ る。 $E_{1}=17 \mathrm{~V}, E_{2}=17 \mathrm{~V}$ としときの出力電圧 $E_{\text {our }}$ を図 3 に例示した。曲線 $(A),(B),(C),(D)$ は入 力回路の可変抵抗 $200 \mathrm{k} \Omega$ の值を変えたときの出力 で, $E_{\mathrm{OUT}}=3 \sim 30 \mathrm{~V}$ の間, 直線的に増加している。更 にこの回路は電源 $E_{1}, E_{2}$ の接点で抵抗 $R_{1}, R_{2}$ を介し て接地されているので，プローブは接地電位に対して ほほ $-E_{2}+E_{\text {OUT }}$ の電位にある。例示の $E_{\text {OUT }}=3 \mathrm{~V}$ の ときは接地電位に対して, $-14 \mathrm{~V}$, また $E_{\mathrm{OUT}}=30 \mathrm{~V}$ のときは接地電位に対して $13 \mathrm{~V}$ の電位にあり,この 間を直線的に変化させることができる。このプローブ 電圧は $4.3 \mathrm{M} \Omega$ と $47 \mathrm{k} \Omega$ で分割されて，ボックスカ

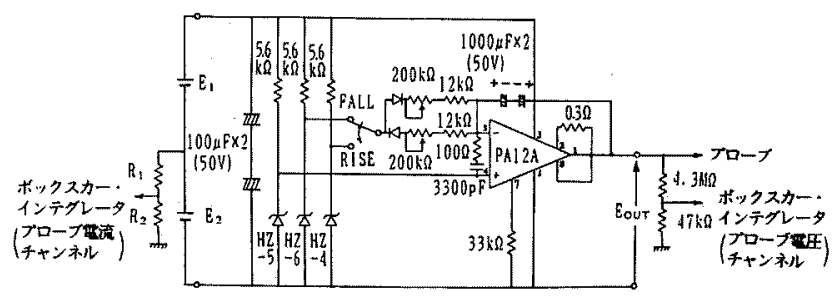

図 2 RAMP 電圧発生回路

Fig. 2. Circuit for probe driving ramp voltage. 


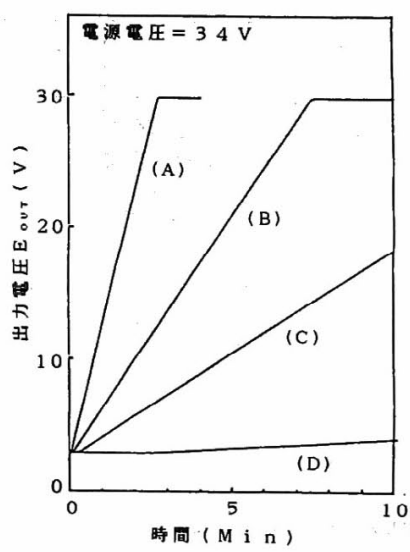

図 3 RAMP 電圧回路出力

Fig. 3. Output of ramp voltage generator.

ーインテグレータ〔エヌエフ回路設計製, 本体 : BX531, サンプリングュニット： $2 \times \mathrm{BP}-10$ (入力インピ ーダンス $1 \mathrm{M} \Omega)$ )に入力して記録計の $X$ 軸を掃引す る。プロープ電流は ramp 電圧電源を通って $R_{1}, R_{2}$ から接地へ流出し， $R_{2}$ の電圧降下がボックスカーイ ンテグレータに入カして記録形の $Y$ 軸を駆動する。 この電流測定用抵抗は $R_{1}+R_{2}=300 \Omega \sim 10 \mathrm{k} \Omega$ の間 で，測定する電流に対応して選択している。また $R_{2} / R_{1} \simeq 1 / 100$ にして, ボックスカーインテグレータ の最大入力 $10 \mathrm{~V}$ を超えないようにしている。

以下の実験ではパルス幅 $T_{\mathrm{ON}}=100 \mu \mathrm{s}$ ，パルス間隔 $T_{\mathrm{OFF}}=1,000 \mu \mathrm{s}$ のパルス放電の特定位相におけるプロ ーブ電圧，プロープ電流を同時にサンプリングしてプ ローブ特性を取得している。サンプリングパルス幅は $1 \mu \mathrm{s}$ に設定し, サンプリング回数は $2^{8}$ 回 $(1.1 \mathrm{~ms} \times$ $256=281.6 \mathrm{~ms}$ ) である。

上記のように，測定対象のアフタグローのプラズマ は接地電位にあり，一方プローブ電圧もサンプリング 期間はほほ一定に保持されているので，プラズマ-プ ローブ間電圧 (シース電圧) は一定とみなすことがて き,応答時間に関する問題はほとんどない。

\section{3. 時間分解プローブ測定}

プローブ特性の測定に先立ち放電管をパルス幅 $T_{\mathrm{ON}}$ $=100 \mu \mathrm{s}$, パルス間隔 $T_{\mathrm{OFF}}=1,000 \mu \mathrm{s}$ の条件下でパル ス放電を行ったときの放電特性を示す。封入圧が高 く, 緩和時間は短いので， $T_{\mathrm{oFF}}=1,000 \mu \mathrm{s}$ はアフタグ ローについて十分の情報を与え得る時間である。図 4 は水銀-3 Torr アルゴン管の放電電圧, 放電電流の波 形, 図 5 は水銀 -6 Torr アルゴン管の放電電圧, 電流

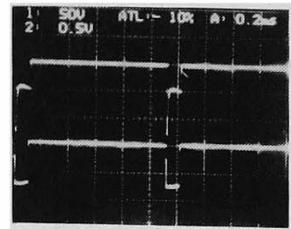

(a) 上: 電圧

$(50 \mathrm{~V} / \mathrm{div}, 200 \mu \mathrm{s} / \mathrm{div})$

下: 電流

$(0.5 \mathrm{~A} / \mathrm{div}, 200 \mu \mathrm{s} / \mathrm{div})$

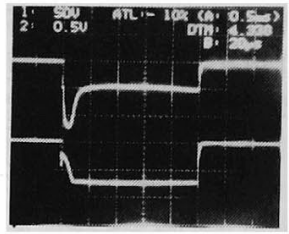

(b) 上：電圧

$(50 \mathrm{~V} / \mathrm{div}, 20 \mu \mathrm{s} / \mathrm{div})$ 下: 電流

$(0.5 \mathrm{~A} / \mathrm{div}, 20 \mu \mathrm{s} / \mathrm{div})$
図 4 水銀-3 Torr アルゴン管の放電電圧, 放電電流波形

Fig. 4. Voltage and current waveforms of Hg-3 Torr Ar lamp.

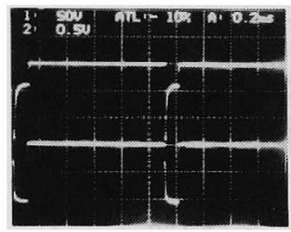

(a) 上：電圧

$(50 \mathrm{~V} / \mathrm{div}, 200 \mu \mathrm{s} / \mathrm{div})$ 下：電流

$(0.5 \mathrm{~A} / \mathrm{div}, 200 \mu \mathrm{s} / \mathrm{div})$

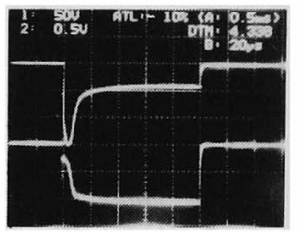

(b) 上：電圧 $(50 \mathrm{~V} / \mathrm{div}, 20 \mu \mathrm{s} / \mathrm{div})$ 下：電流 $(0.5 \mathrm{~A} / \mathrm{div}, 20 \mu \mathrm{s} / \mathrm{div})$
図 5 水銀-6 Torr アルゴン管の放電電圧, 放電電流波形

Fig. 5. Voltage and current waveforms of Hg-6 Torr Ar lamp.

の波形を示す。両図とも(a)図は 2 周期にわたる波 形，(b)図は時間軸を拡大したパルス印加時の波形て ある。放電管の陽極はパルス電源出力回路の MOSFET 2 SK 384 のソースに接続され，常時接地電位に ある。一方，陰極はパルス放電の期間は負の電位にあ り，アフタグローの期間は陽極と同電位，すなわち接 地電位になる。アフタグローのプラズマ（空間）電位 はほほ接地電位にある。

〈3・1〉イオン電流領域図 6 は水銀 -3 Torr $>$ ルゴン管で陽極から $2.5 \mathrm{~cm}$ の位置に設置されたプロ ーブに負の電圧を加えたときのイオン電流のプローブ 特性である。サンプリングの時刻はパルス放電終了後 $60,100,150,200,300,400,600,800,1,000 \mu \mathrm{s}$

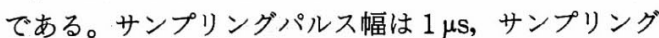
回数は $2^{8}$ 回の条件でプローブ電圧, プロープ電流を 取込んでいる。飽和イオン電流值はサンプリング時刻 が遅くなるほど小さくなり，ほほ予想どおりの結果を 与えているが, $60 \mu \mathrm{s}$ におけるプローブ電流は飽和特 


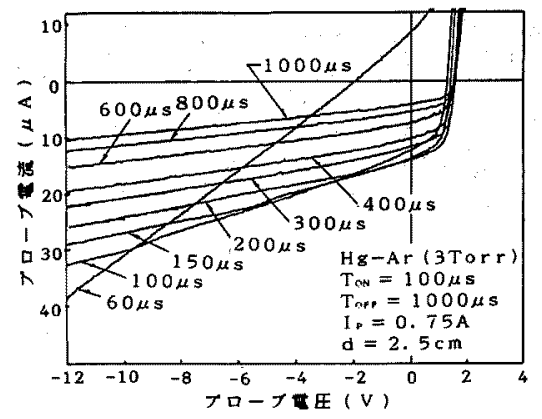

図 6 飽和イオン電流領域のプローブ特性 Fig. 6. Probe characteristics in the region of saturation ion current.

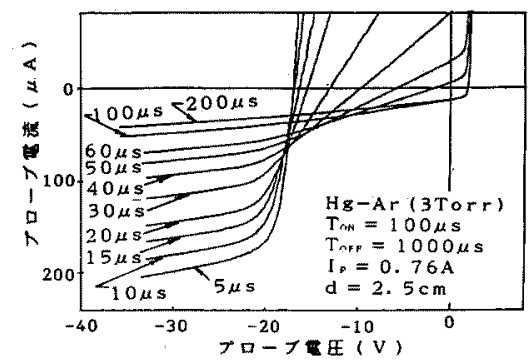

図 7 高エネルギー電子が流入する飽和 イオン電流領域のプローブ特性

Fig. 7. Probe characteristics in the region of saturation ion current, showing the presence of high energy electrons.

性を示していないのが注目される。更に細かく観察す ると $100 \mu \mathrm{s}, 150 \mu \mathrm{s}$ の曲線もやや急こう配で交差して おり,プロープ流入電流は飽和イオン電流だけではな

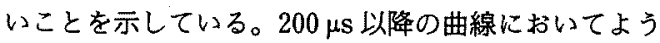
やく飽和イオン電流特性が示されているようである。

図 7 は陽極から $2.5 \mathrm{~cm}$ の位置に設置されたプロー

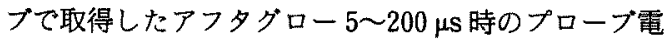
流一電圧特性である。200 $\mu \mathrm{s}$ 時と $100 \mu \mathrm{s}$ 時の曲線は前 図の曲線と同じであるが，数十 $\mu \mathrm{s}$ 以下のアフタグロ 一初期では〜 $-20 \mathrm{~V}$ 以下の低電圧領域で飽和イオン 電流が現れている。そして,プローブ電圧がこの電圧 を超えて高くなるとプローブ電流はかなりのこう配て 増加し始め, 高エネルギーの電子が流入していること を示している。更にプローブ電圧が高くなり， 1.5 Vになると各特性曲線は重量し，ほとんど垂直に電 流は増加している。このような折れ曲がりをもつ特性 曲線は二䉓子温度プラズマを示嘠している。なぜアフ タグロー初期のプラズマは高エネルギー電子を含む 2

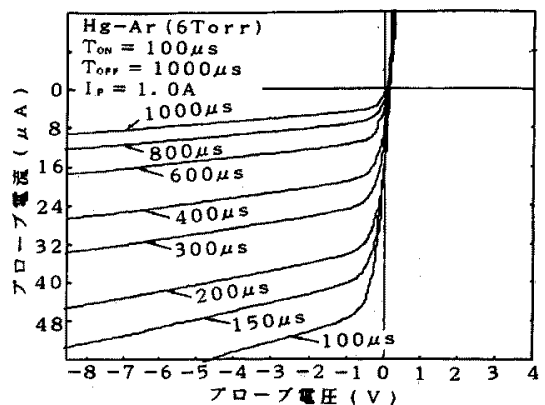

図 8 飽和イオン電流領域のプローブ特性 Fig. 8. Probe characteristics in the region of saturation ion current.

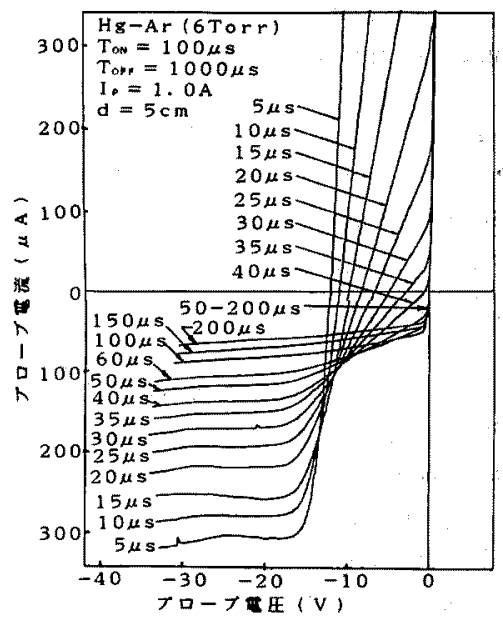

図 9 高エネルギ一電子が流入する飽和 イオン電流領域のプローブ特性

Fig. 9. Probe characteristics in the region of saturation ion current, showing the presence of high energy electrons.

電子温度プラズマであるか, については第 4 章の考察 において検討を加える。

このようなアフタグロー初期のプローブ特性曲線は パルス放電ては一般的に観測される現象であるうか。 水銀-6 Torr アルゴン放電管を用いて飽和イオン電流 領域について追試実験を行った。この測定結果を図 8 , 図 9 に示す。図 8 はパルス放電オフ後 100,150 , $200,300,400,600,800,1,000 \mu \mathrm{s}$ 時の特性曲線て， 一般的な飽和イオン電流特性を示している。しかし図 9 では, $60 \mu \mathrm{s}$ 以内のアフタグロー初期の曲線は -17 〜0Vの電生領域で異常なこう配を示しており，電子 エネルギー分布の tail を形成する高エネルギー電子 の存在を示唆している。この電子エネルギーtail は 
パルス電圧のオフ後, 時間が経過するに従って減少

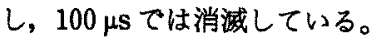

〈3.2〉電子電流領域 プロープ印加電圧を高め て電子が流入する領域のプローブ特性を測定した。図 10, 図 11 は水銀-3 Torr アルゴン管, 水銀-6 Torr ア ルゴン管の測定結果である。アフタグローの電子電流 領域のプロープ測定はプラズマに擾乱を与えるが(9), 本実験ではプローブを極力小さくして $(1 \mathrm{~mm} \times 0.4$ $\mathrm{mm} \phi)$ 観測できるような放電の変動は起こらないよ う押さえた。図では，過渡電流領域と飽和電子電流領 域の境界の折れ曲がりを明確に認めることはできない が，曲線を片対数プロットすることによりはっきり示 されるようになるのは後記するところである。電流の 二次微分が負の領域，すなわち測定した特性曲線にお いて上に凸の領域が飽和電子電流領域であり，また上 に凹の電流立上りの領域が過渡領域であるから，図は

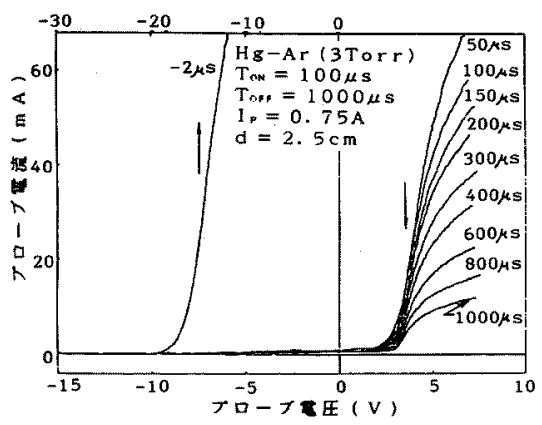

図 10 過渡領域, 飽和電子電流領域の プローブ特性

Fig. 10. Probe characteristics in the regions of transition and saturation electron current.

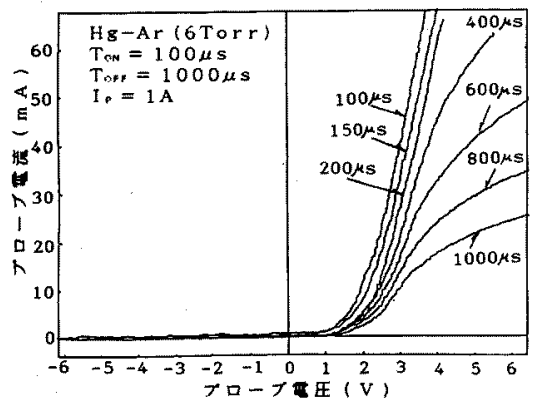

図 11 過渡領域, 飽和電子電流領域の プローブ特性

Fig. 11. Probe characteristics in the regions of transition and saturation electron current.

学論A，112 巻 4 号，平成 4 年
流入電子電流の全貌を示している，と考えてよい。図

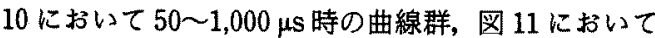
は 100 1,000 $\mu \mathrm{s}$ 時の曲線群はほぼ同じプローブ電圧 て立ち上がり，また飽和電流値は時間の経過と共に小 さくなり，予想どおりの結果を与えている。図 10 の $-2 \mu \mathrm{s}$ 時の曲線はパルス放電を遮断する前 $2 \mu \mathrm{s}$ の特 性曲線, すなわちパルス電圧印加時の特性曲線で他の

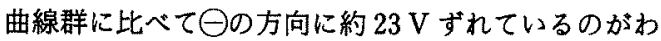
かる（電圧軸の目盛は図の上に記す）。この二つの状

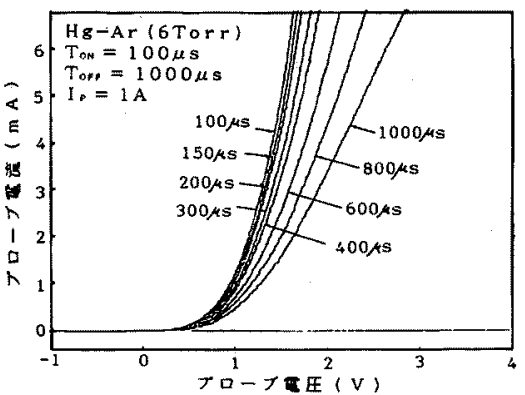

(a)

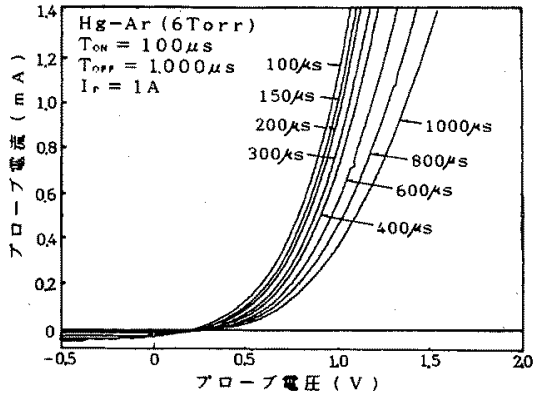

(b)

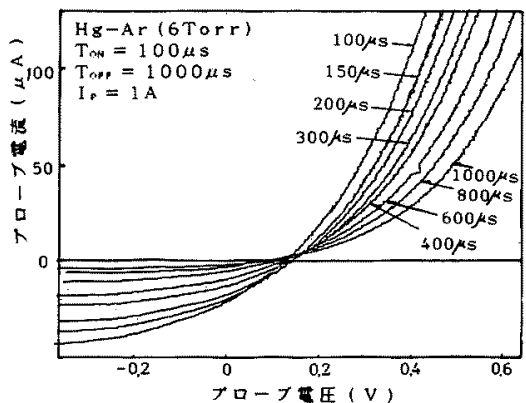

(c)

図 12 座標軸の目盛を変えて記録した 3 枚 のプローブ特性図

Fig. 12. Three diagrams of the probe characteristics recorded on different scales of the current and voltage coordinates. 
態間の移行はパルス電圧遮断後〜 $5 \mu \mathrm{s}$ 以内で行われる ことを確認している。なお奏測のプローブ特性曲線か ら片対数表示 $\log I_{P}-V_{P}$ の関係を再プロットするには 電流軸, 電圧軸の尺度を抗大した特性曲線を取得し， より正確なデータを知る必要がある。図12(a)〜 (c) は, 電流剆定抵抗 $R_{1}, R_{2}$ 順次取替无（図 1 参 照)，水銀-6 Torrアルゴン管で測定した一連の特性 曲線であって, 各時刻における曲線の相互関係, 電流 が増加する程度などの詳細を観察することができ，各 曲線から正確なデー夕を読取ることができる。

かくして，取得したこれらの曲線を片対数表示する と, 図 13, 図 14 に示す典型的なプローブ特性が得ら

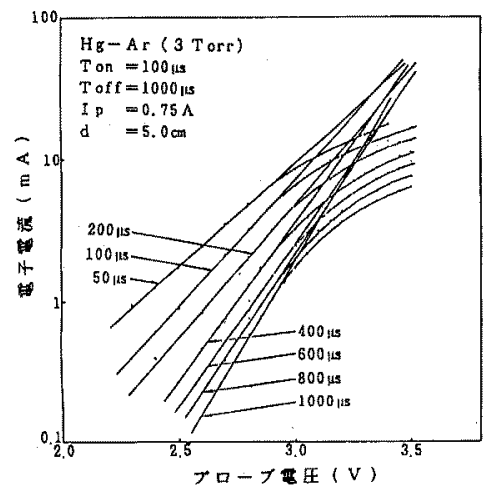

図 13 水銀-3 Torr アルゴン・アフタグロー のプローブ電流-電圧特性

Fig. 13. Semi-logarithmic plot of probe characteristics for $\mathrm{Hg}-3$ Torr $\mathrm{Ar}$ after. glow.

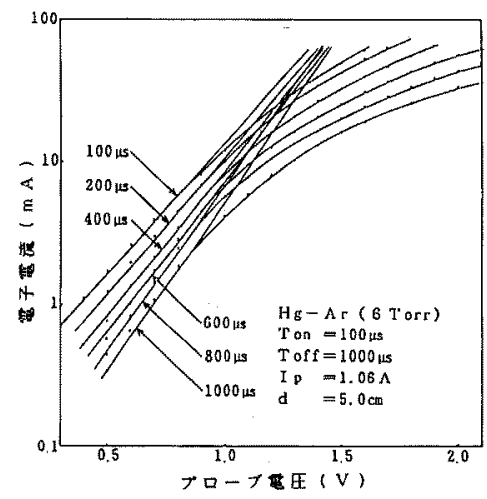

园 14 水銀-6 Torr アルゴン・アフタグロ一 のプローブ電流-電圧特性

Fig. 14. Semi-logarithmic plot of probe characteristics for $\mathrm{Hg}-6$ Torr $\mathrm{Ar}$ afterglow.
れる。なお電子電流はプロープ電流を次式で補正して プロットしている。

$$
I_{e}=I_{p}+I_{i}
$$

ここて $I_{e}:$ 電子電流, $I_{p}:$ プロープ電流;

$I_{i}:$ イオン電流（飽和イオン電流領域の電流

を過渡電流領域まで直線的に延長し，各電圧

におけるイオン電流とした）

両図ともアフタグローの時間経過と共に直線部のこ う配は急になり（電子温度は低くなり），電子電流は 小さくなる（プラズマ密度は減少する）のを認めるこ

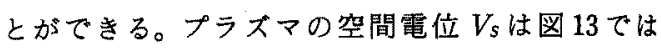
$\sim 3.0 \mathrm{~V}$, 図 14 では〜0.9Vにある。

〈3・3〉要子温度 水銀-3 Torr アルコン管, 水 銀-6 Torr アルゴン管について测定した一次データを 示したが，以下低圧放電管の代表として前者 3 Torr アルコン管のデータを整理して，若千のプラズマ物理 量を求める。

さて, 放電管内のプラズマ密度分布は零次のベッセ ル関数と仮定すると， $1 \mathrm{~mm} \times 0.4 \mathrm{~mm} \emptyset$ 円柱型プロ 一ブに流入する電子電流 $I_{e}$ は, 先端断面に流入電流 と円柱側面に流入する電流の和として, 次式で表すこ とができる。

$$
\begin{aligned}
I_{e} & =\frac{1}{4} e \bar{c} n_{0}\left(A_{1}+A_{2}\right) \exp \left\{-\frac{e\left(V_{s}-V\right)}{k T_{e}}\right\} \\
& =I_{e 0} \exp \left\{-\frac{e\left(V_{s}-V\right)}{k T_{e}}\right\} \cdots \cdots \cdots \cdots \cdots \cdots
\end{aligned}
$$

ただし，

$$
\begin{aligned}
& n_{0} A_{1}=\pi r_{0}^{2} n_{0} J_{0}\left(\frac{2.4}{R} r_{1}\right) \cdots \cdots \cdots \cdots \cdots \\
& n_{0} A_{2}=\int_{r_{1}}^{r_{1}+L}\left\{2 \pi r_{0} n_{0} J_{0}\left(\frac{2.4}{R} r\right)\right\} d r
\end{aligned}
$$

ただし， $e$ : 電子電荷, $\bar{c}:$ 電子の平均速度, $n_{0}$ : 電子の軸上密度, $k$ : ボルッマン定数, $T_{e}$ : 電子温度, $V_{S}:$ プズマの空間電位 $(\sim 3.0 \mathrm{~V}), V:$ プローブ電压, $I_{e 0}:$ 飽和電 子電流, $r_{0}:$ プローブ半径 $(0.2 \mathrm{~mm}), L$ : プロープの長さ $(1 \mathrm{~mm}), r_{1}$ : 放電管軸から プロープ先端までの距離 $(1 \mathrm{~mm}), R:$ 放電 管内半径 $(6.5 \mathrm{~mm})$

(2) 式の対数をとると

$$
\log I_{e}=-\frac{e}{k T_{e}}\left(V_{s}-V\right)+\log I_{e 0}
$$

となり, $\log I_{e}-V$ 特性のこう配から電子温度を求め ることができる。うして得られた電子温度をアフタ グローの経過時間の関数として図 $15(\mathrm{a}),(\mathrm{b})$ に示 के 
電子温度はパルス放電をオフした直後の $15,000 \mathrm{~K}$ から $50 \mu \mathrm{s}$ 経過後の約 $3,000 \mathrm{~K}$ まては急速に，以降は きわめて緩やかに低下している。この電子温度は主と して電子とアルゴン原子の弾性衝乫により低下してい る。電子温度の低下を妨げる要因として電子と水銀準 安定原子 $\left(6^{3} \mathrm{P}_{2}\right)$ との間の超弾性衝突による電子の加 熱が論じられている(9)。著者らの場合，この衝突に関 与する準安定原子の密度の実測値をもうていないが, 共鳴線 2,537 A 線を放出する共鳴原子 $\left(6^{3} \mathrm{P}_{1}\right)$ との間 で熱平衡状態が保たれていると考えると，準安定原子 $\left(6^{3} \mathrm{P}_{2}\right)$ の密度を推定することができる。 $6^{3} \mathrm{P}_{2}$ と $6^{3} \mathrm{P}_{1}$ が平衡状態にあれば同じ速度で減衰するが，すでに $6{ }^{3} \mathrm{P}_{1}$ の密度の指針となる $2,537 \mathrm{~A}$ 線放射強度は放電終 了後, アフタグロー $10 \mu \mathrm{s} て ゙ 1 / 2$ に低下し, $50 \mu \mathrm{s}$ 経 過して〜1/50に低下していることがわかってい $る^{(10)}$ 。また，放電プラズマ中の準安定原子 $6^{3} \mathrm{P}_{2}$ の密 度は放電電流に対して飽和する傾向にあり, 飽和値は 水銀-3.5 Torr アルゴン管にるおいて $7.6 \times 10^{11} \mathrm{~cm}^{-3} て ゙$ あることが知られている(11)。著者らの放電において

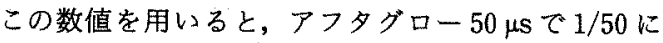
減少して $1.5 \times 10^{10} \mathrm{~cm}^{-3}$ となる。一方，弹性衝突に関 与する 3 Torr のアルゴン原子密度は $1.1 \times 10^{17} \mathrm{~cm}^{-3}$ で, 上記水銀準安定原子密度の $7 \times 10^{6}$ 倍である。電 子-アルゴン原子間の弾性衝笑損失係数 $3 \times 10^{-5}$ を考 慮しても, 弾性衝突が電子温度を決定する中心的役割 を果たしている，と推察することができる。かくして 電子温度は次式に従って低下する, と考党て検討を加 える。

$$
\frac{d T_{e}}{d t}=-2 \frac{m_{e}}{M} \nu_{\mathrm{coi}}\left(T_{e}-T_{B}\right)
$$

ここで, $m_{e}$ :電子質量, $M:$ アルゴン原子

質量, $T_{e}$ : 電子温度, $T_{g}:$ 気体温度 そして $\nu_{\text {col }}$ は

$$
\nu_{\mathrm{col}}=\frac{4 \pi}{U_{e}} \int_{0}^{\infty}(1 / 2) m_{e} v^{4} \nu(v) f(v) d v
$$

ここで, $U_{e}:$ 電子平均エネルギー $(=3 / 2$ ・

$\left.n_{e} k T_{e}\right), f(v)$ : 電子速度分布, $n_{e}$ : 電子密度

で与えられるエネルギー移送に関する平均衝突周波数 である。 $\nu$ は衝突周波数で, 電子速度 $v$ (あるいは電 子エネルギー $\left.U_{e}\right)$ の関数としてデータが与えられて いるが，このデー夕を使って計算するにあたっては速 度のべき乗で近似する方法がある(12)。

$$
\nu(v)=\nu_{0} v^{h}
$$

アルゴンでは $0.5 \mathrm{eV}<U_{e}<10 \mathrm{eV}$ のネルギー簌囲 で $h=3.3$ がよく合うとされているが(13)，しかしべき 乗近似の式をRamsauer極小值を超えて低エネルギ
一領域まで拡張するには少なくとももう1項のべき乗 項を付け加える必要がある。以下の計算では, McPherson らのデータ(14)を参照して最小二乗法近似 で求めた次式を用いる。

$$
\nu(v)=9.0 \times 10^{32} p v^{-3.5}+5.2 \times 10^{-19} p v^{3.4}
$$

ここで, $p$ は Torr, $v$ は $\mathrm{cm} / \mathrm{s}$ の単位で表した圧力お よび電子速度である。（9)式を(7)式に代入して積分 を遂行すると

$$
\nu_{\mathrm{col}}=1.3 \times 10^{12} p T_{e}^{-1.75}+370 p T_{e}^{1.7}
$$

となる。 $T_{e}$ には絶対温度 $\mathrm{K} て ゙$ 表した数值を適用す る。(10)式を(6)式に代入し, 数值計算した結果を図 15(a)，（b）に併記して示した。パルス放電をオフし た直後の温度を $15,000 \mathrm{~K}$ に設定して計算してあるが, アフタグローの初期に温度は急速に低下し，例えば $50 \mu \mathrm{s}$ 後には $2,300 \mathrm{~K}, 100 \mu \mathrm{s}$ 後には $1,600 \mathrm{~K} に な り ，$ 漸次緩やかに低下していくのがわかる。

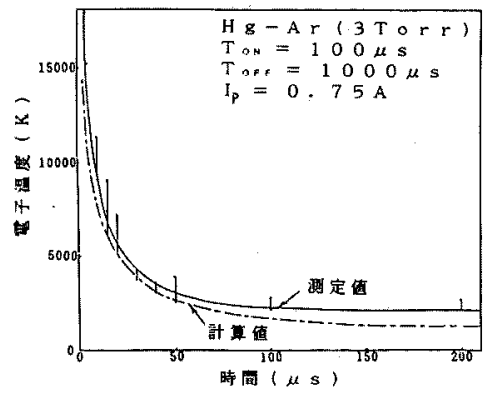

(a)

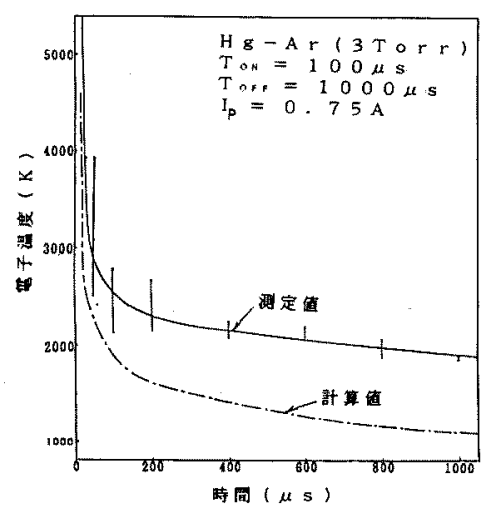

(b)

図 15 アフタグローの電子温度

Fig. 15. Variation of electron temperature in the afterglow. 


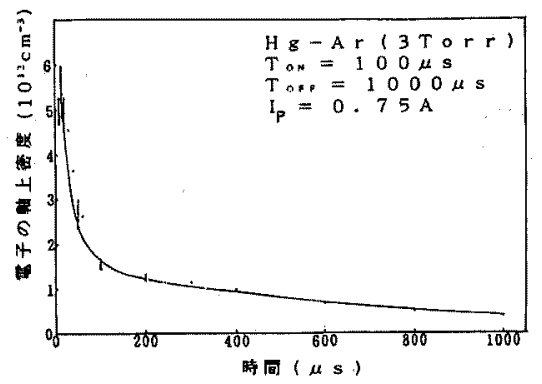

図 16 アフタグローのプラズマ密度

Fig. 16. Decay of plasma density in the afterglow.

実験結果と比べて，計算による温度のほうがやや速 く低下するようである。既に述べたように，アルゴン 封入压は 3 Torr でやや高いが, $T_{e}=2,000 \mathrm{~K}(\bar{c}=3.1$ $\left.\times 10^{7} \mathrm{~cm} \cdot \mathrm{s}^{-1}\right)$ における平均衝突周波数は(10)式から $\nu_{\text {col }}=4.5 \times 10^{8} \mathrm{~s}^{-1}$, 平均自由行程は $\lambda=0.7 \mathrm{~mm}$ であ る。プローブの半径 $r_{0}=0.2 \mathrm{~mm}$ に比べてやや大き い。またシースの厚さの尺度となるデバイ長 $l_{D}$ は次 式で与えられ

$$
\frac{1}{l_{D}^{2}}=\frac{e^{2} n_{i}}{\varepsilon_{0} k T_{i}}+\frac{e^{2} n_{e}}{\varepsilon_{0} k T_{e}} \simeq \frac{e^{2} n_{i}}{\varepsilon_{0} k T_{i}}
$$

ここで, $\varepsilon_{0}:$ 真空の誘電率, $n_{i}, T_{i}:$ イオン 密度, イオン温度, $n_{e}, T_{e}$ : 電子密度, 電子 温度

プラズマ密度 $n=10^{12} \sim 10^{11} \mathrm{~cm}^{-3}$ のアフタグローで は（図 16 参照) $l_{D}=0.0015 \sim 0.0048 \mathrm{~mm}$ となる。 $\lambda \gg$ $l_{D}$ の条件が成立しているから，シース中の衝突はほ とんど問題にならず, 図 15 の測定值と計算值の間の 若干の不一致を補正することはできない。

〈3.4〉プラズマ密度空間電位に拈けるプロー プ電流

$$
I_{e 0}=e \sqrt{\frac{k T_{e}}{2 \pi m_{e}}} n_{0}\left(A_{1}+A_{2}\right)
$$

から放電管軸上のプラズマ密度 $n_{0}$ を計算した。計算 には電子温度測定值を用いている。プローブから平均 自由行程 $\lambda=0.7 \mathrm{~mm}$ 離れた点でプローブ（半径 $r_{0}=$ $0.2 \mathrm{~mm}$ ) を見こむ立体角と全立体角の比は～ $5 \%$ であ るから，プロープによる shadowing 効果は無視して いる。図 16 は,こうして求めたプラズマ密度をアフ タグローの経過時間の関数として示した減衰曲線であ る。室温における 3 Torr アルゴン管のプラズマでは 水銀原子イオンがイオンの主体をなしており(2)，その 損失は両極性拉散によるから，プラスマ密度は指数関

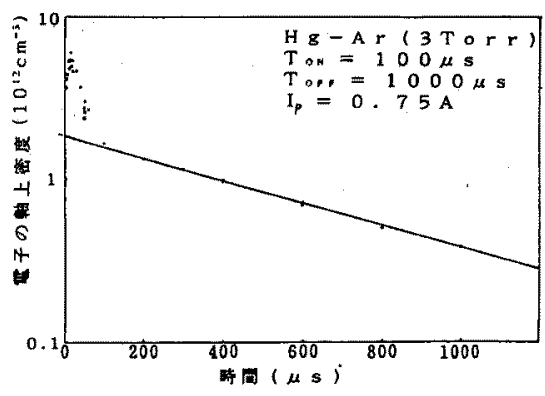

図 17 アフタグロープラズマ密度の 片対数表示

Fig. 17. Semi-logarithmic plot of plasma density in the afterglow.

数的隇衰を示す。

$$
n_{0}(t)=n_{0}(0) \exp \left\{-\left(D a / \Lambda^{2}\right) t\right\}
$$

ここで, $D a:$ 両極性㹡散係数, $\Lambda$ : 拡散長 $(=0.65 / 2.4 \mathrm{~cm})$

図 17 は図 16 を片対数グラフにプロットし直した図 であるが, プラズマ密度は(13)式に従って直線的に滅 衰している。減衰の時定数 $630 \mu \mathrm{s}$ 加ら，兩極性拡散 係数 $D a p=350 \mathrm{~cm}^{2} \cdot \mathrm{s}^{-1}$ ・Torr が得られる。別報の再 結合放射の減衰加ら求めた両極性拡散係数は $D a p=$ $300 \mathrm{~cm}^{2} \cdot \mathrm{s}^{-1} \cdot$ Torr であり(2)，またChanin らのアルゴ ン中の水銀イオン移動度(15) から求めた数值は $D a p=$ $360 \mathrm{~cm}^{2} \cdot \mathrm{s}^{-1} \cdot$ Torr で，これらの数值は比較的よい一 致を示している。

\section{4，異常プローブ特性についての考察}

以上，パルス放電アフタグローを対象とした時間分 解プローブ測定の実験結果を示してきたが，パルス放 電では初めて観察され，そして異常な特性と考えられ

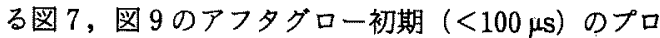
一ブ特性に検討を加える。すなわち，これらの図では 飽和イオン電流領域から過渡電流領域にかけて異常な こう配が現れ，高速電子のプローブヘの流入が示唆さ れている。

さて，電子エネルギー分布の tail 部に寄与する高 速電子はビーム状プラズマ (beam-like plasma) 中 に多量存在する(16)といわれており，例えば熱除極放 電管の陰極直前のプローブ測定でもその存在が確かめ られている(3)。陰極降下電圧で加速された電子がプラ ズマに突入し，そのエネルギーを保持しているのであ る。

では，このような高速電子がパルス電圧印加時から 


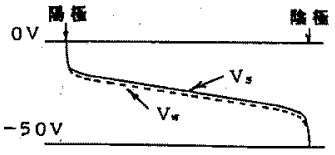

（a） パルス电压印加時

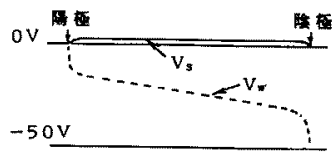

(b) アフタグロー初期

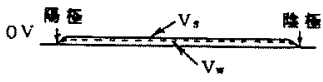

(c) アフタグロ-後期

図 18 パルス放電の空間電位と管壁電位

Fig. 18. Space and wall potentials at various phases of the pulse discharge.

アフタグローに移行する過渡的過程でなぜ発生するの だろうか，定性的には次のように考えることができ る。図 10実験装置構成図に示してあるが, 放電管の 陽極はつねに接地されているので，パルス電圧印加時 にはプラズマの空間電位 $V_{s}$ ，管壁電位 $V_{w}$ は図 18(a)のようになる。陰極は－50 V（図 4, 図 5) にあり，陰陽極間にわたって $V_{w}$ は $V_{s}$ よりやや低め であるが，ほほ同電位にある。パルス放電を才フする と，数 $\mu$ S以内に陰陽極間の電圧は零になり（図 4, 図 5 参照)，従って空間電位 $V_{s}$ も同じ速さで接地電 位になるが，管壁電位 $V_{w}$ はそれほど速やかに接地電 位になるとは限らない。むしろ，(b)図の電位分布を とると考えられる。管壁電位がプラズマ塋間電位に追 随できない遅れ時間は，イオンが管壁に流入して管壁 電位が上がり， $V_{s} \simeq V_{w}$ になるまでの時間であって， 軸近傍のプラズマから管壁までイオンが走行するのに 要する時間に近いものと思われる。イオンが管壁に流 入し， $V_{s} \simeq V_{w}$ になったとき，電位分布は(c)図に移 行する。

さて，アフタグローの初期，もし(b)図のような電 位分布が形成されると，管壁近くに存在した電子は放 電管の軸に向かって加速され， $V_{s}-V_{w}$ の電位差に相 当するエネルギーをもつ高速電子が発生する。本実験 で観察された異常プローブ電流はこの高速電子による ものと思われる。

以上は○のパルス電圧を陰極に加えたときのアフタ グローのプローブ特性について述べてきた。円のパル
ス電圧を陽極に加えたときはこのような現象は観測さ れないと考えられるが，これは本研究の延長線上にあ る一つの研究課題である。

\section{5.むすび}

水銀-3 Torr アルゴン放電管，および水銀-6 Torr アルゴン放電管をパルス放電し，そのアフタグローを 対象として時間分解プローブ測定を行い，下記の結論 安得た。

（1）立上り時間が数分の ramp 電圧をプローブに 加え，アフタグローの特定時刻におけるプローブ電 流，プローブ電圧をサンプリングした。測定曲線はア フタグローの大半の期間で, 飽和イオン電流領域, 過 渡領域，飽和電子電流領域に固有の特性を示した。

（2）アフタグローの各時刻におけるプローブ特性 曲線から求めた電子温度の冷却曲線と，衝突周波数の 近似式を用いて計算した冷却曲線を比較検討した。

（3）アフタグローの各時刻におけるプローブ特性 曲線から求めたプラズマ密度は，指数関数的に減衰す る。この減衰曲線加ら, 両極性拡散係数 $D a p=$ $350 \mathrm{~cm}^{2} \cdot \mathrm{s}^{-1}$. Torr を得た。

（4）パルス放電をオフした直後，プローブに高速 電子が流入するという異常現象を見いだし，この高速 電子の発生機構に検討を加えた。

日ごろ貴重な御教示をいただいている名古屋大学 武田 進名誉教授および研究会メンバーの方々に厚く 感謝する。研究遂行にあたりいろいろ御援助いただい た日立製作所松野博光氏，浜本信男氏にも媣く感謝 する次第である。

(平成 3 年 6 月 24 日受付，同 3 年 10 月 25 日再受付)

\section{文献}

（1）山根：「低圧水銀-アルゴン・アフタダローの再結合放射」、 電学諭 $A, 110,483$ (平 2-8)

（2）山根，他：「水銀一希ガスアフタグローにおける再結合放射 の諸特性了, 同上 A, 111, 888 (平 3-10)

(3) I.F. Waymouth: "Pulse Technique for Probe Measurements in Gas Discharges", J. Appl. Phys., 30, 1404 (1959)

(4) D. G. Bills, et al. : "Pulsed Probe Measurements", ibid., 33, 29 (1962)

(5) A. B. Stewart: "Oscillating Glow Discharge Plasma", ibid., 27, 911 (1956)

(6) A. Garscadden, et al. : "Langmuir Probe Measurements in the Presence of Oscillations", Rev. Sci. Instrum., 35, 912 (1964)

(7) K. F. Schoenberg: "Pulsed Electrostatic Probes as a Diag nostic for Transient Plasmas", ibid., 49, 1377 (1978)

(8) K. Ohe et al: "Time-Resolved Electron Energy Distribution Function in Time-Varying Weakly Ionized Plasmas", Japan. J. Appl. Phys., 28, 1997 (1989)

(9) M. Sugawara et al.: "Electron Density and Temperature Decay in Mercury Afterglows", Phys. Rev. A, 2, 439 (1970)

（10）山根，他：「パルス放電に扝ける低圧水䤵ーアルゴンブラス 
マの時間分解分光」, 電学論 A, 109,231 (平元-6)

(11) C. Kenty : "Production of 2537 Radiation and the Role of Metastable Atoms in an Argon-Mercury Discharge", $J$. Appl. Phys., 21, 1309 (1950)

(12) J. Polman et al. : "Nonlinear Effects in the Positive Column of a Strongly Modulated Mercury-Rare Gas Discharge", J. Phys. D: Appl. Phys., 5, 266 (1972)

(13) B. L. Wright, et al. : "Radiation Temperature of a Bounded Nonthermal Plasma. Experiment", Phys. Fluids, 14, 1773 (1971)

(14) D. A. McPherson, et al. : "Microwave Transient-Response Measurements of Elastic Momentum-Transfer Collision Frequencies in Argon", Phys. Rev., 13, A167 (1976)

(15) L. M. Chanin et al. : "Mobilities of Mercury Ions in $\mathrm{He}, \mathrm{Ne}$ and Ar", ibid., 107, 1219 (1957)

(16) M. B. Hopkins, et al.: "Electron Energy Distribution Function Measurements in a Magnetic Multipole Plasma", J. Phys. D : Appl. Phys., 20, 838 (1987)

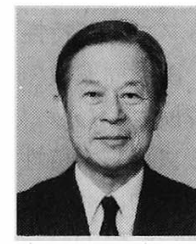

\section{山 根 幹 也 (正員)}

昭和 28 年東京大学理学部物理学科卒 業。同年 4 月日立製作所入社。中央研究 所に勤務, 主として気体放電, プラズマ の研究，およびこの分野に関連する機
器, デバイスの開発に従事。59 年日立製作所中央研究所 を退社，アマダメトレクス(株)に常勤顧問，技師長として 入社。60 年電気通信大学短期大学部教授。62 年電気通信 大学電気通信学部教授, 現在に至る。工学博士。日本物理 学会会員。

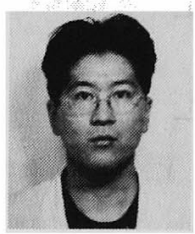

\section{名 取 乾 治 (非会員)}

昭和 41 年 7 月 30 日生。平成 2 年 3 月 電気通信大学電気通信学部卒業。同年 4 月同大学大学院電気通信学研究科博士前 期課程入学。現在に至る。

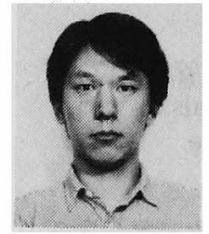

\section{石 田 信 之（非会員）}

昭和 36 年 2 月 27 日生。 60 年九州大 学理学部中退。6 63 年電気通信大学勤務。 現在に至る。 